\title{
An assessment of the value of electron microscopy in tumour diagnosis
}

\author{
C FISHER, AD RAMSAY, M GRIFFITHS, J MCDOUGALL
}

From University College London School of Medicine, London WC1

SUMMARY The contribution of electron microscopy to the diagnosis of tumours in a general hospital has been investigated. During a three year period 235 cases were examined, of which 66 (28\%) were diagnostic problems by light microscopy. In $42(64 \%)$ of the problem cases a contribution towards diagnosis was made by ultrastructural examination, which was most useful for anaplastic polygonal cell tumours, of some value for spindle cell neoplasms, and least helpful in the further categorisation of metastatic carcinoma.

Although most neoplasms can be identified at the light microscopic level, there remain several important areas where precise categorisation may be difficult or impossible. These include, for example, the undifferentiated polygonal cell tumour with a differential diagnosis of carcinoma, lymphoma, achromic melanoma, or epithelioid sarcoma; the spindle cell tumour which may be a sarcoma, melanoma, or squamous carcinoma; and more specitic problems such as the small round cell tumour of childhood (rhabdomyosarcoma, Ewing's sarcoma, neuroblastoma, lymphoma, or leukaemia).

Additional information from electron microscopic examination, derived from considerations of cellular relations, membrane specialisations, and the nature and patterns of intracellular structures, may result in a more precise diagnosis in many such cases, with consequent effect on patient management. In a further group of tumours a provisional light microscopic diagnosis may be confirmed by electron microscopy or, on occasion, refuted.

The application of electron microscopy to oncology has been increasingly advocated in recent years, together with accounts of ultrastructural features enabling categorisation of tumours. ${ }^{1-9}$ Few studies, however, have quantitated the value of electron microscopy in tumour diagnosis in the non-specialist hospital. We have examined the contribution of electron microscopy to the diagnosis of tumours in the routine laboratory service of a general (undergraduate teaching) hospital over a three year period and have attempted to identify the clinicopathological problems in which electron microscopy may be expected to help and those in which it is of less value.

Accepted for publication 4 December 1984

\section{Material and methods}

SOURCES OF MATERIAL

In the UK it is usual for surgically excised specimens to be placed in formalin fixative in the operating theatre, which gives less than optimal fixation for electron microscopy. Surgeons were asked to cooperate either by sending the whole tumour or biopsy to the pathology department without delay or by placing a suitably sized portion in glutaraldehyde as well as fixing the majority of the specimen in $10 \%$ formol-saline in the usual way. Small bottles of $4 \%$ glutaraldehyde in $0.125 \mathrm{M}$ phosphate buffer were kept for this purpose at $4^{\circ} \mathrm{C}$ in the operating theatre suite.

Samples of tumours were collected from the following sites: the head and neck, soft tissues, lymph nodes, and endocrine glands, and from other sites where unusual appearances or a previous biopsy indicated a potential diagnostic problem. Tumours sent for frozen section diagnosis were a substantial source of material since the pathologist was immediately aware of a diagnostic difficulty and could preserve a portion of tissue for electron microscopy.

Formalin fixed tissue was also submitted for electron microscopy when it was the only tissue available after light microscopy had disclosed the desirability of electron microscopic examination. Although the results from this were less satisfactory, it was always worth attempting, and on occasion tissue was retrieved from paraffin block. ${ }^{10}$

PROCESSING AND EXAMINATION

After $3-4 \mathrm{~h}$ fixation in glutaraldehyde at room temperature, the tissue fragments were washed and stored in phosphate buffer at $4^{\circ} \mathrm{C}$ until light micros- 
copy was available and a decision made to proceed to electron microscopic examination. If this was delayed the tissue was processed and stored in resin block.

Light microscopic examination included the use of standard special staining techniques where indicated but did not include immunohistochemistry, which was not in routine use in our laboratory during the first two years of this study. Electron microscopic examination was performed: (a) when the light microscopic diagnosis was contentious or inconclusive or (b) when electron microscopy was expected to provide confirmatory or characteristic findings substantiating the provisional light microscopic diagnosis.

All tissue was postfixed in $1 \%$ osmium tetroxide in phosphate buffer, dehydrated with ethanol, and embedded in Araldite. Processing usually took 48$72 \mathrm{~h}$ but when required an electron microscopic section could be ready in 18-24 h. Four to eight blocks were prepared for each case, and sections cut on a Reichert ultramicrotome at $0.5-1.0 \mu \mathrm{m}$ were stained with toluidine blue and examined to confirm the presence of tumour. Ultrathin sections of selected areas were stained with uranyl acetate and lead citrate, mounted on copper grids, and examined and photographed in a Phillips EM 200 electron microscope.

\section{ASSESSMENT OF THE VALUE OF ELECTRON MICROSCOPIC EXAMINATION}

In order to assess the contribution of electron microscopy to the final diagnosis, each case was placed in one of three categories:

1 Those in which ultrastructural findings significantly advanced or narrowed a problematic or incomplete light microscopic diagnosis, sometimes providing a histogenetic label. Thus anaplastic tumour to carcinoma (or sarcoma or melanoma), or carcinoma to squamous carcinoma, or lymphoma to malignant histiocytosis were all considered advances in the level of diagnosis.

2 Those problems posed by light microscopy where electron microscopy failed to show any discriminating features which would solve the problem or advance the level of diagnosis.

3 Cases diagnosed by light microscopy in which findings on electron microscopy were supportive or confirmatory. In these instances electron microscopy was utilised not for problem solving but was regarded as "an extra high power on the microscope." This category included poorly differentiated tumours assigned by light microscopy to a definite diagnosis (whereas in group 1 only a differential diagnosis was given by light microscopy).

\section{Results}

A total of 425 specimens were received for selection for electron microscopy, in 167 of which light microscopy was diagnostic or no tumour was present. During this period the total number of surgical pathology accessions was 21250 .

The remaining 258 cases were selected for electron microscopic examination, of which about two thirds were received in glutaraldehyde and the rest derived equally from tissue sent for frozen sections and from formalin fixed reserve tissue. After processing, no tumour was found in semithin sections in 23 samples; this left 235 cases (92\% of those selected) for ultrastructural study.

The anatomical sources of the neoplasms are shown in Table 1 . The principal sites were lymph nodes ( $21 \%$ of cases), head and neck (14\%), lung $(14 \%)$, soft tissues $(10 \%)$, gastrointestinal tract $(8 \%)$, skin $(8 \%)$, bone $(6 \%)$, endocrine glands $(5 \%)$, and mediastinum $(5 \%)$; all other sites together comprised the remaining $9 \%$. Electron microscopy was supportive or confirmatory in 169 cases. An assessment of the contribution of electron microscopy towards the final diagnosis is also shown in Table 1 (see Methods). Sixty six cases were problematic on light microscopy. In 24 instances no specific information was obtained to advance the light microscopic impression, but a significant contribution was thought to have been made in 42 $(64 \%)$ of the difficult cases.

The types of problem dealt with in each site and the final diagnoses are shown in Tables 2 and 3. In Table 4 the 66 difficult cases are analysed according to the nature of the diagnostic problem. Electron microscopy was of particular value in undifferentiated polygonal cell tumours by identifying carcinoma or melanoma and by suggesting sarcoma or lymphoma. In this category no single diagnosis predominated, although (Table 3 ) half $(9 / 18)$ were interpreted as carcinomas without squamous or glandular features. Five of these cases (22\%) remained uncharacterised.

Spindle cell tumours were also identified by electron microscopy as fibroblastic, melanocytic, or epithelial (squamous). Electron microscopy, however, was of little value in identifying the source of metastatic carcinoma, particularly adenocarcinoma: in only two of 17 cases was a primary site suggested.

Fixation in glutaraldehyde produced the most technically satisfactory results, those from formalin fixed tissue varying considerably. In some instances cell junctions, cytoplasmic filament patterns, or dense core granules were discernible, but in other cases loss of cell membrane and disruption of organelles rendered the material valueless. Tissue 
Table 1 Summary of all cases by site of origin

\begin{tabular}{|c|c|c|c|c|c|c|}
\hline \multirow[b]{2}{*}{$\begin{array}{l}\text { Site or system of } \\
\text { origin of biopsy }\end{array}$} & \multirow[b]{2}{*}{$\begin{array}{l}\text { No of cases } \\
\text { received }\end{array}$} & \multirow[b]{2}{*}{$\begin{array}{l}\text { No tumour } \\
\text { present }\end{array}$} & \multirow[b]{2}{*}{$\begin{array}{l}\text { No of cases } \\
\text { examined }\end{array}$} & \multicolumn{3}{|c|}{ Role of electron microscopy } \\
\hline & & & & $\begin{array}{l}\text { Significantly } \\
\text { contributory }\end{array}$ & Non-contributory & Confurmatory \\
\hline $\begin{array}{l}\text { Bone } \\
\text { Bladder } \\
\text { Endocrine } \\
\text { Gastrointestinal tract } \\
\text { Head and neck } \\
\text { Kidney (tumours) } \\
\text { Lung } \\
\text { Lymph node } \\
\text { Marrow } \\
\text { Mediastinum } \\
\text { Skin } \\
\text { Soft tissue } \\
\text { Testis } \\
\text { Other } \\
\quad \text { Brain } \\
\text { Liver } \\
\text { Gynae } \\
\text { Spleen } \\
\text { Breast } \\
\text { Total }\end{array}$ & $\begin{array}{r}17 \\
6 \\
20 \\
20 \\
108 \\
5 \\
48 \\
94 \\
10 \\
13 \\
28 \\
34 \\
9 \\
13 \\
4 \\
2 \\
6 \\
1 \\
1 \\
425\end{array}$ & $\begin{array}{r}7 \\
10 \\
4\end{array}$ & $\begin{array}{r}13 \\
3 \\
12 \\
19 \\
34 \\
2 \\
32 \\
50 \\
1 \\
12 \\
19 \\
23 \\
8 \\
7 \\
2 \\
1 \\
3 \\
0 \\
0 \\
235\end{array}$ & $\begin{array}{l}3(23 \%) \\
1(33 \%) \\
2(17 \%) \\
1(5 \%) \\
9(26 \%) \\
5(16 \%) \\
8(16 \%) \\
\\
5(26 \%) \\
5(22 \%) \\
3(43 \%) \\
2 \\
1 \\
42(18 \%)\end{array}$ & $\begin{array}{l}14(28 \%) \\
1(100 \%) \\
1(1 \%) \\
1(5 \%) \\
2(9 \%) \\
1(14 \%)\end{array}$ & $\begin{array}{r}10 \\
2 \\
10 \\
15 \\
24 \\
2 \\
27 \\
28 \\
11 \\
13 \\
16 \\
8 \\
3 \\
2 \\
2 \\
1\end{array}$ \\
\hline
\end{tabular}

The last three columns assess the contribution of electron microscopy to the final diagnosis (see Methods).

Table 2 Cases in which electron microscopy helped to advance the diagnosis by narrowing the differential or by providing a definitive histogenetic label

\begin{tabular}{|c|c|c|c|c|}
\hline Site of origin & Nature of problem & No of cases & Final diagnosis & Number \\
\hline Bone & Small cell anaplastic tumour & 3 & $\begin{array}{l}\text { Metastatic carcinoma of lung } \\
\text { Ewing's tumour }\end{array}$ & $\begin{array}{l}1 \\
2\end{array}$ \\
\hline $\begin{array}{l}\text { Bladder } \\
\text { Endocrine }\end{array}$ & $\begin{array}{l}\text { Spindle cell tumour } \\
\text { Malignant lymphoma of thyroid }\end{array}$ & $\begin{array}{l}1 \\
1\end{array}$ & $\begin{array}{l}\text { Leiomyosarcoma } \\
\text { Histiocytosis X }\end{array}$ & 1 \\
\hline Head and neck & $\begin{array}{l}\text { Spindle cell tumour of thyroid } \\
\text { Round cell anaplastic tumour (nasopharynx) }\end{array}$ & $\begin{array}{l}1 \\
6\end{array}$ & $\begin{array}{l}\text { Carcinoma } \\
\text { Carcinoma ( } 3 \text { squamous, } 1 \text { adeno) } \\
\text { Lymphoma } \\
\text { Melanoma }\end{array}$ & $\begin{array}{l}1 \\
4 \\
1 \\
1\end{array}$ \\
\hline & Spindle cell tumour & 2 & $\begin{array}{l}\text { Myoepithelioma (parotid) } \\
\text { Rhabdomyosarcoma (nose) }\end{array}$ & $\begin{array}{l}1 \\
1 \\
1\end{array}$ \\
\hline Gastrointestinal & Lymphoma & 1 & $\mathrm{~T}$ cell lymphoma & 1 \\
\hline $\begin{array}{l}\text { tract } \\
\text { Lung }\end{array}$ & $\begin{array}{l}\text { Lymphoid tumour } \\
\text { Anaplastic tumour }\end{array}$ & $\begin{array}{l}1 \\
4\end{array}$ & $\begin{array}{l}\text { Malignant histiocytosis } \\
\text { Small cell carcinoma } \\
\text { Squamous carcinoma } \\
\text { Melanoma }\end{array}$ & $\begin{array}{l}1 \\
2 \\
1 \\
1\end{array}$ \\
\hline Lymph node & $\begin{array}{l}\text { Adenocarcinoma } v \text { mesothelioma } \\
\text { Metastatic carcinoma ?Primary site }\end{array}$ & $\begin{array}{l}1 \\
3\end{array}$ & $\begin{array}{l}\text { Mesothelioma } \\
\text { Alveolar cell carcinoma } \\
\text { Renal cell carcinoma } \\
\text { Squamous cell carcinoma }\end{array}$ & $\begin{array}{l}1 \\
1 \\
1 \\
1\end{array}$ \\
\hline & Anaplastic tumour & 4 & $\begin{array}{l}\text { Metastatic carcinoma } \\
\text { Lymphoma }\end{array}$ & $\begin{array}{l}1 \\
1 \\
3\end{array}$ \\
\hline Skin & $\begin{array}{l}\text { Pleomorphic sarcoma } \\
\text { Anaplastic tumour }\end{array}$ & 1 & $\begin{array}{l}\text { Malignant fibrous histiocytoma } \\
\text { Melanoma } \\
\text { Lymphoma }\end{array}$ & $\begin{array}{l}1 \\
2 \\
1\end{array}$ \\
\hline & $\begin{array}{l}\text { Lymphoma ?mycosis fungoides } \\
\text { Spindle cell tumour }\end{array}$ & 1 & $\begin{array}{l}\text { Follicle centre cell lymphoma } \\
\text { Melanoma }\end{array}$ & 1 \\
\hline Soft tissues & Spindle cell tumour & 3 & $\begin{array}{l}\text { Metastatic carcinoma (squamous cell } \\
\text { carcinoma) }\end{array}$ & 1 \\
\hline & Anaplastic tumour & 1 & $\begin{array}{l}\text { Malignant fibrous histiocytoma } \\
\text { Malignant schwannoma } \\
\text { Metastatic adenocarcinoma }\end{array}$ & $\begin{array}{l}1 \\
1\end{array}$ \\
\hline Other & $\begin{array}{l}\text { Adenocarcinoma } v \text { chordoma } \\
\text { Breast ? Melanoma } \\
\text { Spindle cell tumour of vagina } \\
\text { Spindle cell tumour of placenta }\end{array}$ & $\begin{array}{l}1 \\
1 \\
1 \\
1\end{array}$ & $\begin{array}{l}\text { Chordoma } \\
\text { Carcinoid } \\
\text { Leiomyoma } \\
\text { Leiomyoma }\end{array}$ & $\begin{array}{l}1 \\
1 \\
1 \\
1\end{array}$ \\
\hline
\end{tabular}


Table 3 Cases in which electron microscopy failed to advance the light microscopic diagnosis

\begin{tabular}{|c|c|c|}
\hline Site of tumour & Nature of problem & $\begin{array}{l}\text { No of } \\
\text { cases }\end{array}$ \\
\hline \multicolumn{3}{|l|}{ Gastrointestinal } \\
\hline tract & $\begin{array}{l}\text { Adenocarcinoma ?Primary site } \\
\text { Colonic tumour ?Carcinoid }\end{array}$ & $\begin{array}{l}2 \\
1\end{array}$ \\
\hline \multirow[t]{4}{*}{$\begin{array}{l}\text { Head and neck } \\
\text { Lymph node }\end{array}$} & $\begin{array}{l}\text { Adenocarcinoma ?Primary site } \\
\text { Metastatic adenocarcinoma }\end{array}$ & 1 \\
\hline & ?Primary site & 9 \\
\hline & Metastatic spindle cell tumour & 1 \\
\hline & Anaplastic tumour uncharacterised & 4 \\
\hline Marrow. & Metastatic carcinoma ?Primary site & 1 \\
\hline Mediastinum & Metastatic carcinoma ?Primary site & 1 \\
\hline Skin & Spindle cell tumour ?Nature & 1 \\
\hline Soft tissues & Spindle cell sarcoma ?Type & 2 \\
\hline Other & Anaplastic tumour of cervix uteri & 1 \\
\hline
\end{tabular}

retrieved from paraffin block was poorly preserved and yielded useful information in only one case.

\section{Discussion}

This study has identified some of the problems in which electron microscopy is likely to be helpful in the diagnosis of tumours in a non-specialist hospital. In 42 of 66 cases unresolved by light microscopy the diagnosis was significantly advanced after ultrastructural examination. These 42 represented $18 \%$ of all cases examined, and within the larger regional subgroups a similar proportion was consistently found.

Electron microscopy is of most value when diag- nosis depends on showing features which are specific such as melanosomes or neurosecretory granules. It is of lesser but definite value when cell identification requires the summation of features which may individually be found in a variety of cell types. Thus of -23 anaplastic polygonal cell tumours, $18(78 \%)$ showed evidence of carcinoma or melanoma or features suggestive of lymphoma. Half of these were finally designated as carcinoma. Spindle cell tumours were further characterised in 10 of 14 cases $(71 \%)$ as sarcomas of various types, carcinoma, or melanoma.

Specific diagnostic questions could occasionally be answered, as in the subcategorisation of lymphoreticular tumours or the distinction between adenocarcinoma and mesothelioma. The small numbers of such cases in our series, however, implies that the contribution of electron microscopy to such problems is limited; certainly in the latter problem the ultrastructural differences between the two tumours can be extremely subtle and the diagnosis is likely to be made on electron microscopy alone.

Electron microscopy was of least value in the further diagnosis of a carcinoma. Although squamous or glandular differentiation could be detected in a metastatic carcinoma, the organ could rarely be determined, and in 14 of 16 adenocarcinomas no further clues were obtained.

Table 4 Contribution of electron microscopy towards the resolution of light microscopic problems

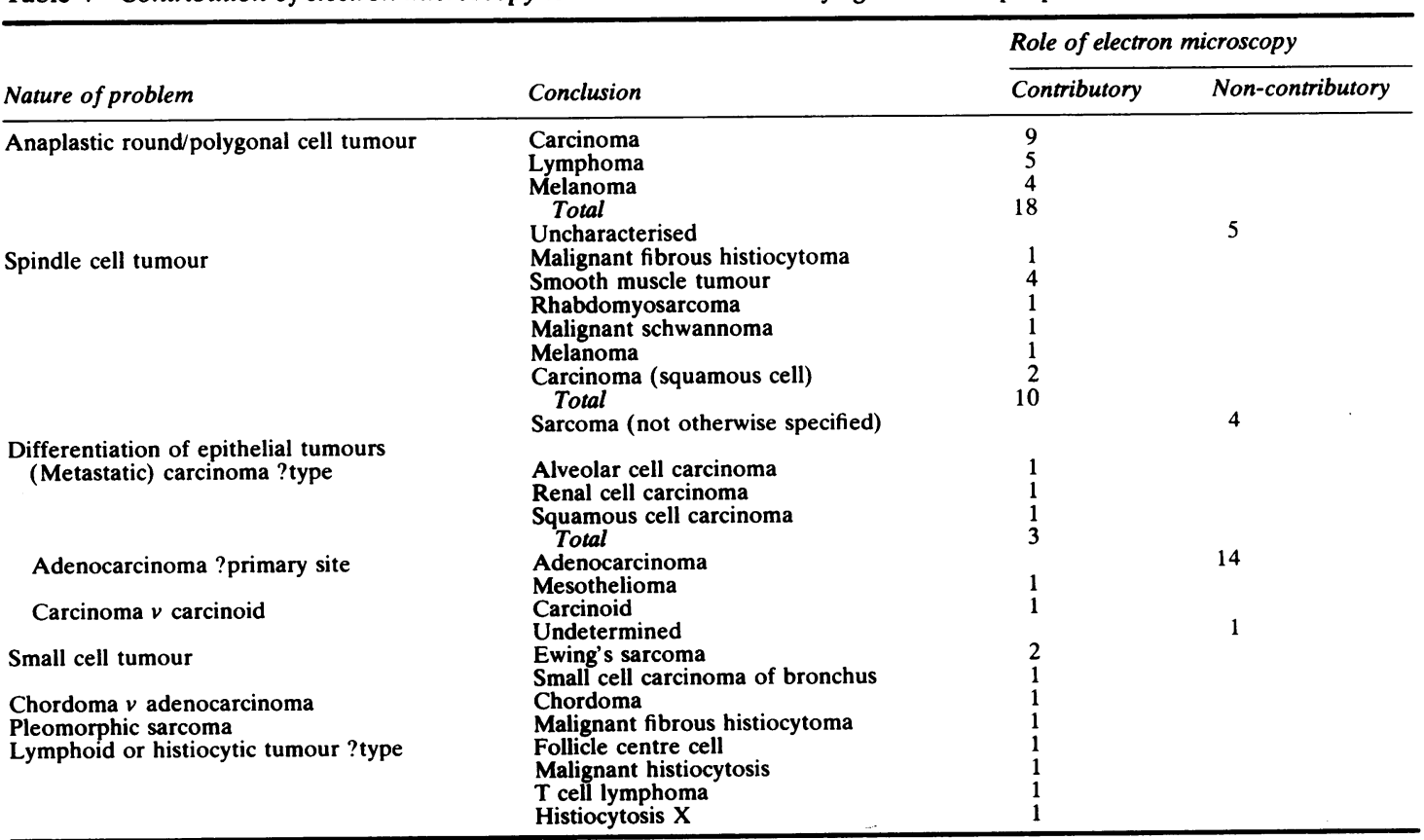


Other studies have highlighted the same findings, although detailed quantitation has not often been performed. Gyorky et $a^{2}$ examined over 2000 specimens in a 10 year period and found that $8 \%$ needed electron microscopy for diagnostic confirmation (an average of 16 cases a year). In $3 \%$ of these the diagnosis was determined by electron microscopy alone, whereas equivocal light microscopy was confirmed in 5\%. At the MD Anderson Hospital, MacKay and Ordonez ${ }^{4}$ examined 1859 tumours in a 12 month period (out of 24000 accessions) and concluded that in most cases electron microscopy reinforced a tentative light microscopic diagnosis or narrowed the differential by exclusion. No additional information was yielded beyond what could have been gained by careful light microscopy in only $10 \%$ of their cases, which implies a greater degree of selectivity than in some other studies. In a more detailed analysis of fewer cases, Kuzela $e$ al $^{8}$ looked at 40 tumours in one year and found that in $18 / 40$ $(45 \%)$ electron microscopy made certain a tentative light microscopic diagnosis, in 11 it confirmed a certain light microscopic diagnosis, and in a further 11 (27\%) provided a more specific histogenetic diagnosis. This compares with our figures which, using different criteria, show that a more specific histogenetic diagnosis could be made in $64 \%$ of cases.

A recent report from the Veterans Administration Pathology Service" examined the uses of diagnostic electron microscopy in surgical pathology over a one month period in 20 hospitals. Of the 290 cases examined $62 \%$ were malignant tumours, and a positive diagnostic contribution was considered to have been made by electron microscopy in $57 \%$ of these. A further point of interest in this study is that the proportion of malignancies in the specimens selected for ultrastructural examination was three times greater than their proportion in the total surgical pathology throughput, which implies that tumours are specifically selected for electron microscopy with a high expectation of its diagnostic value.

As part of a larger investigation, in 40 lymph node tumours where light microscopy was inconclusive Diebold et al ${ }^{12}$ found that $26(65 \%)$ could be further diagnosed by electron microscopy, of which 21 were carcinomas ( 10 adenocarcinomas, 3 squamous carcinomas, and 8 undifferentiated). None of the adenocarcinomas could be subcategorised, a limitation of electron microscopy also noted in our study.

Other limitations of electron microscopy are well known. They include the fact that only small areas can be sampled, which may not include tumour (as in $9 \%$ of our cases) and which may not be representative, leading to false negative results. This is said to be a particular problem with sarcomas, ${ }^{13}$ which may vary considerably in histology from area to area.
Our subsequent experience with over 180 soft tissue tumours has indicated that in histologically identical cells specific submicroscopic features may be present in only a few, indicating the need to sample several blocks.

In most of our cases electron microscopy was merely supportive or confirmatory of light microscopy. This is in itself of value, but study of such cases is additionally desirable for two reasons. Firstly, most ultrastructural features are common to a variety of cells. For example, intercellular junctional specialisations, including desmosomes (maculae adherentes) are considered to be characteristic of epithelial cells but have also been described to varying degrees in tumours which may be morphologically similar to carcinomas. These include mesothelioma, ${ }^{14}$ synovial $^{15}$ and epithelioid sarcoma, ${ }^{16}$ and nerve sheath tumours, ${ }^{17}$ neuroblastoma, ${ }^{18}$ and Ewing's sarcoma, ${ }^{19}$ as well as in other situations. Indeed, in a recent report junctions were described between tumour cells and polymorphonuclear leucocytes. ${ }^{20}$

Secondly, poor light microscopic differentiation is often paralleled at the ultrastructural level, so that neoplastic junctions may be scanty and poorly formed, resembling the focal membrane densities seen in many non-epithelial tumours, including those of histiocytes.21 The characterisation of tumours with minimal light microscopic differentiation depends on the summation of several features and requires familiarity with a wide range of appearances. This experience can be gained only by examining numerous examples of different tumours showing varying degrees of differentiation. For these reasons, we regard confirmatory or supportive cases as an essential part of the work of an electron microscopic unit.

Some of the above problems may be elucidated by immunohistochemical techniques. The specificities of many individual antisera are still being established, ${ }^{22-25}$ but in theory the diagnosis of anaplastic polygonal cell tumours, for example, may be aided by the use of a panel of monoclonal antibodies to cytokeratins and to lymphoid cells. ${ }^{26}$ Only one ${ }^{y}$ of the reports quantitating the value of electron microscopy in tumour diagnosis discusses the role of immunohistochemistry in the light microscopic assessment of their cases. Immunohistochemistry and electron microscopy are complementary in tumour diagnosis and should not be regarded as alternatives. A parallel study assessing the relative contributions of these techniques would, however, be of great interest.

In all cases, including those where the diagnosis may be partly one of exclusion, correlation with the light microscopy and with the clinical features is 
essential: malignancy must almost always be diagnosed by light microscopy, and few diagnoses can be made on an electron microscopic picture alone. In clinical practice, consideration of the complete case history is essential.

Electron microscopy is often regarded as an expensive procedure, and it is instructive to attempt to assess its cost. In 1975, an early Veterans Administration study ${ }^{27}$ suggested a figure of $\$ 100$ per case, based on 250 cases per year, and cited a range in US hospitals of $\$ 52$ to $\$ 200$. In a British paper in $1977,{ }^{4}$ which took into account capital costs over 10 years, technical salaries, service contracts, and consumables, a figure of $£ 20$ per case was reached, and a further $£ 10$ added for the salary of a consultant pathologist occupied for half his time in electron microscopy.

An electron microscopy unit in a general hospital deals not only with tumours but also with renal, skin, and muscle biopsies, and in some instances with microbiological work as well. If we assume a proportion of the expenses in relation to workload, however, and allow for one wholetime technician for tumour work, a similar calculation (excluding depreciation) gives a figure of $£ 90$ per case in our three year series. To this could be added $£ 12 \cdot 50$, which represents the salary of a National Health Service consultant for one hour. At the Royal Marsden Hospital/Institute of Cancer Research similar considerations for internal costing purposes have resulted in a levy of $£ 84$ per case (based on 200 tumour cases per year in 1983-4), a closely comparable figure. Since consumables form the smallest component of the overall expenses, the unit cost will fall with increasing numbers of cases examined, up to the point where further staff are needed; one technician can deal with 150-200 cases per year. Although the relevance of such assessments may be questionable, electron microscopy for tumour diagnosis should not be regarded as an excessively expensive investigation. We hope, however, that studies of this type will lead to greater selectivity with more efficient and economic use of the facility.

This study was carried out with the support of the Special Trustees of University College Hospital. We are grateful to Mrs Hilary McPhail for technical assistance and to Professor JF Smith for help and advice throughout the study.

\section{References}

' Rosai J, Rodriguez HA. Application of electron microscopy to the diagnosis of tumours. Am J Clin Pathol 1968;50:555-62.

${ }^{2}$ Gyorkey F, Min K-W, Krisko I/ Gyorkey P. The usefulness of electron microscopy in the diagnosis of human tumours. Hum Pathol 1975; 6:421-41.

${ }^{3}$ Bonikos DS, Bensch KG, Kempson RL. The contribution of electron microscopy to the differential diagnosis of tumours. Beiträge zur Pathologie 1976;158:417-44.
${ }^{4}$ Carr I, Toner PG. Rapid electron microscopy in oncology. J Clin Pathol 1977;30:13-15.

${ }^{5}$ Mackay B, Osborne BM. The contribution of electron microscopy to the diagnosis of tumours. Pathobiol Ann 1978; 8:359-405.

- Mackay B, Silva EG. Diagnostic electron microscopy in oncology. Pathol Ann 1980;15:241-70.

' Chaudry AP, Cutler LS, Montes M, Satchidanand S, Raj MS. Electron microscopy: its application in diagnostic pathology. $N$ $Y$ State J Med 1980;80:1809-24.

${ }^{8}$ Kuzela DC, True LD, Eiseman B. The role of electron microscopy in the management of surgical patients. Ann Surg 1982;195: 1-11.

"Mackay B, Ordonez NG. The role of the pathologist in the evaluation of poorly differentiated tumours. Semin Oncol $\vec{\omega}$ 1982;9:396-415 9:396-415

${ }^{10}$ Johannessen JV. The use of paraffin material for electron microscopy. Pathol Ann 1977;12:189-224.

Williams MJ, Uzman BG. Uses and contributions of diagnostic electron microscopy in surgical pathology: a study of 20 Veterans Administration hospitals. Hum Pathol 1984;15:738-45.

12 Diebold J, Reynes M, Tricottet V. Electron microscopy in the diagnosis of malignant adenopathies. Paper given at the International Academy of Pathology electron microscopy symposium: differential diagnosis of tumours. Brussels, May 1984

${ }^{13}$ Ross J, Hendrickson MR, Kempson RL. The problem of the poorly differentiated sarcoma. Semin Oncol 1982;9:467-83.

14 Davis JM. Ultrastructure of human mesotheliomas. J Natl Cancer Inst 1974;52:1715-25.

is Dische FE, Darby AJ, Howard ER. Malignant synovioma: electron microscopical findings in three patients and review of the literature. J Pathol 1978;124: 149-55.

${ }^{10}$ Gabbiani G, Fu YS, Kaye GI, Lattes R, Majno G. Epithelioid sarcoma-a light and electron microscopic study suggesting synovial origin. Cancer 1972;30:486-99.

17 Alvira MM, Mandybur TI, Menefee MG. Light microscopic and ultrastructural observations of a metastasizing malignant epithelioid schwannoma. Cancer 1977;38:1977-82.

${ }^{18}$ Conde E, Lafarga M, Bureo E, et al. Unusual ultrastructural findings in neuroblastoma. Cancer 1982;50:1115-21.

${ }^{19}$ Llombart-Bosch A, Blache R, Peydro-Olaya A. Ultrastructural study of 28 cases of Ewing's sarcoma: typical and atypical forms. Cancer 1978;41:1362-73.

${ }^{20}$ Tang C-K. Intercellular junction formation between polymorphonuclear leukocytes, and between polymorphonuclear leukocytes and tumour cells. Ultrastructural Pathology 1983;5: $153-62$.

${ }^{21}$ Henry K, Farrer-Brown G. A colour atlas of thymus and lymph node histopathology. London: Wolfe Medical Publications, 1981:280.

${ }^{22}$ Erlandson RA. Diagnostic immunohistochemistry of human tumours. An interim evaluation. Am J Surg Pathol 1984;8:615-24.

${ }^{23}$ Delsol G, Gatter KC, Stein H, et al. Human lymphoid cells $O$ express epithelial membrane antigen. Lancet 1984;ii:1124-8.

24 Brooks JJ. Immunohistochemistry of soft tissue tumours: progress and prospects. Hum Pathol 1982;13:969-74.

${ }^{25}$ Eusebi V, Bondi A, Rosai J. Immunochemical localization of myoglobin in nonmuscular cells. Am J Surg Pathol 1984; 8:51-5.

${ }^{26}$ Gatter KC, Abdulaziz Z, Beverley P, et al. Use of monoclonal antibodies for the histopathological diagnosis of human malignancy. J Clin Pathol 1982;35:1253-67.

${ }^{27}$ Azar HA, Morningstar WA, Vracko R, White HJ. Problems in the development of a clinically oriented program in electron microscopy. Hum Pathol 1975;6:485-9.

Requests for reprints to: Dr C Fisher, Royal Marsden Hospital, Fulham Road, London SW3 6JJ, England. 